\title{
СТРУКТУРА ГОТОВНОСТІ МАЙБУТНІХ ЕКОНОМІСТІВ ДО ПРОФЕСІЙНОЇ ДІЯЛЬНОСТІ ТА НЕПЕРЕРВНОЇ САМООСВІТИ
}

\author{
(C) Кірдан О.П., 2019 \\ http://orcid.org/0000-0003-2667-6589 \\ http://doi.org/10.34142/2312-2471.2019.61.08
}

У статті обгрунтовано структуру готовності майбутніх економістів до професійної діяльності та постійної самоосвіти, щзо забезпечує здобуття студентами вищої освіти готовності до діяльності у изому напрямку, їх доступ до рівня постійного професійного та особистісного саморозвитку та самовдосконалення. На основі аналізу наукових працьь вітчизняних та зарубіжних дослідників запропоновано авторське визначення поняття «готовність майбутніх економістів до професійної діяльності та неперервної освіти» як інтегративне особистісне утворення, щзо $\epsilon$ результатом професійної підготовки у закладах вищої освіти та охоплює здатність провадити ефективну професійну економічну та неперервну самоосвітню діяльність, спрямовану на професійно-особистісний розвиток відповідно до особистих потреб та актуальних професійних вимог до фахівців-економістів. Виокремлено сутнісні характеристики та індикатори готовності майбутніх економістів до професійної діяльності та неперервної самоосвіти: особистісна мотивація та суб'єктивне значення професійної діяльності та безперервна самоосвіта; незалежність та ефективність професійної діяльності за фахом, наступність та систематичність професійной самоосвіти; цілеспрямованість та активність професійної рефлексї, самовиховання, саморозвиток, самовдосконалення. Висвітлено перелік показників готовності майбутніх економістів до професійної діяльності та неперервної самоосвіти, щзо охоплюють різні ї̈ аспекти. Обгрунтовано та схарактеризовано мотиваційно-ціннісний, когнітивний, операційно-діяльнісний та рефлексійно-поведінковий компоненти готовності майбутніх економістів до професійної діяльності та неперервної самоосвіти. А саме: мотиваційноияіннісний (мотиваційно-ціннісна сфера, прагнення до досягнення успіху, готовність до постійної самоосвіти тощуо); пізнавальний (галузь компетенцї, формування теоретичних знань та практичних навичок, включаючи постійну самоосвіту тощуо); оперативний (здатність до ефективної професійной діяльності та постійне самовиховання тощо) та рефлексивно-поведінковий (рефлекторні здібності, здатність розвивати індивідуальний стиль економічної поведінки, формувати індивідуальну професійну концепиію тощзо) компоненти.

Ключові слова: готовність до професійної діяльності; майбутні економісти; структура готовності; індикатори готовності; компоненти 
готовності; неперервна самоосвіта; система неперервної освіти; заклади вищзӧ освіти.

\section{Kirdan O.P. The Structure of Preparedness of Future Economists for Professional Activity and Continuous Self-Education}

The article substantiates the structure of readiness of future economists for professional activity and continuous self-education, which ensures that higher education students acquire readiness for activity in this direction, their access to the level of continuous professional and personal self-development and selfimprovement. Based on the analysis of scientific works of national and foreign researchers, the author's definition of the concept «readiness of future economists for professional activity and continuous self-education» is: an integrative personal essence, including the ability to conduct effective professional economic and continuous self-educational activities aimed at professional and personal development in accordance with personal needs and current professional needs, requirements for economists. The following essential characteristics of readiness for professional activity and continuous self-education are singled out: personal motivation and subjective significance of professional activity and continuous selfeducation; independence and efficiency of professional activity in the specialty, continuity and systematicity of professional self-education; purposefulness and activity of professional reflection, self-education, self-development, self-improvement. The list of indicators of readiness of future economists for professional activity and continuous self-education is covered, covering its various aspects. The components of readiness of future economists for professional activity and continuous self-education are singled out and characterized: motivational-value (motivational-value sphere, aspiration to achieve success, readiness for continuous self-education, etc.); cognitive (competence area, formation of theoretical knowledge and practical skills, including continuous self-education, etc.); operational (ability to effective professional activity and continuous self-education, etc.) and reflective-behavioral (reflective ability, the ability to develop an individual style of economic behavior, to form an individual professional concept, etc. components).

Key words: readiness for professional activity; future economists; readiness structure; readiness indicators; readiness components; continuous self-education; system of continuous education; institutions of higher education.

Постановка проблеми. Поняття «готовність до професійної діяльності» поряд із поняттям «професійна компетентність» широко використовується у педагогіці, психології, акмеології. У освітніх програмах та навчальних планах підготовки майбутніх економістів у сучасних закладах вищої освіти значна увага надається формуванню загальних та професійних компетентностей. Однак ї реалізація здійснюється виключно через обмежену кількість теоретичних навчальних дисциплін або дисциплін за вибором здобувачів вищої освіти. 
Рефлексія власного досвіду підприємницької діяльності та викладання у закладі вищої освіти уможливлюють ствердження, що готовність до професійної діяльності не може грунтуватись виключно на утилітарній підготовці: набуттю знань і розвитку умінь. Тому готовність майбутніх фахівців до професійної діяльності доцільно розглядати не тільки як передумову, а й як регулятор діяльності, так як до іiі структури входять «дієві» знання і властивості особистості, що забезпечують їй максимальну результативність.

Аналіз останніх досліджень і публікацій. У сучасному психологопедагогічному дискурсі низка праць вітчизняних та зарубіжних дослідників присвячена проблемі формування готовності майбутніх фахівців до професійної діяльності, самоосвіти та професійного саморозвитку. У наукових розвідках М. Голованя, Г. Дутки, О. Ссіної, Л. Максимчук, Е. Остапенко, Т. Поясок, В. Третька та ін. схарактеризовано процес формування готовності майбутніх економістів до професійної діяльності.

На переконання Л. Максимчук, у вищій школі «підготовка студентів спрямовується на формування готовності майбутніх фахівців до професійної діяльності», а професійна компетентність майбутніх економістів-міжнародників «оцінюється рівнем сформованості професійних вмінь», до яких дослідниця зараховує такі: гностичні, організаційно-дидактичні, комунікативнорежисерські, прогностичні, рефлексивні, загально-професійні, конструктивнотехнологічні (Максимчук Л.В., 2013).

У дисертаційній роботі Е. Остапенко наголошено, що «першочерговим завданням професійної підготовки $є$ формування особистості-професіонала, здатної до неперервної освіти та самовдосконалення, готової до постійного особистісного та професійного саморозвитку» (Остапенко Е.О., 2015).

Виділення невирішених раніше частин загальної проблеми. Отже, у наукових працях вказано на потребу формування готовності майбутніх фахівців до професійної діяльності та неперервної самоосвіти. Водночас, структура готовності майбутніх економістів до професійної діяльності потребує детального аналізу та наукового осмислення, оскільки узалежнена від тенденцій соціального замовлення суспільства.

Мета статті - виокремити та схарактеризувати індикатори та компоненти готовності майбутніх економістів до професійної діяльності та неперервної самоосвіти.

Виклад основного матеріалу. Нині соціум, роботодавці висувають власні вимоги до готовності професіонала-економіста. Зазначимо, що у дослідженні О. Ссіної виокремлено такі значущі показники сформованості готовності до професійної діяльності як: «уміння думати самостійно i вирішувати різноманітні професійні проблеми, мати критичне i творче мислення та багатий словниковий запас» (Єсіна О.Г., 2012, с. 87).

Дослідниця вказала найголовніші якості особистості, які, на наш погляд, $€$ базовими у характеристиці готовності майбутніх економістів до професійної діяльності, а саме: здатність адаптуватися у професійних та життєвих ситуаціях, самостійно здобувати знання, вміло використовувати їх у практичній 
діяльності; чітко усвідомлювати напрями застосування набутих знань у практичній діяльності; здатність генерування нових ідей, креативного мислення; самовдосконалення та розвиток власної моральності інтелекту, культурного рівня, комунікабельності, уміння працювати в команді (Єсіна О.Г., 2012, c. 87).

На переконання І. Зязюна, головною метою вищої освіти повинно бути становлення цілісної і цілеспрямованої особистості, готової до вільного гуманістично орієнтованого вибору, що набула багатофункціональних компетентностей (Зязюн I.А., 2005, с. 10-18).

Викладене вище уможливлює розгляд готовності майбутніх економістів до професійної діяльності як синонім професійної компетентності, згідно із компетентнісним підходом. При цьому, якщо кожна компетентність $\epsilon$ «здатністю» до певної дії, то готовність до виконання тієї ж дії включає не тільки «здатність», а й мотивацію, бажання і можливість здійснення цієї дії.

Отже, незважаючи на окремі розходження в трактуваннях понять «готовність до діяльності», «готовність до професійної діяльності» різних авторів, єдиним є розгляд готовності як результату складної, багатоаспектної особистісної освіти. Результатом професійної підготовки майбутніх економістів у системі неперервної освіти, як спеціально організованого освітнього процесу 3 реалізації освітніх програм на певному рівні вищої освіти, $\epsilon$ набуття готовності (інтегрує теоретичний, мотиваційний, практичний iï складники) майбутніми економістами до професійної діяльності та неперервної самоосвіти.

Формування готовності майбутніх економістів до професійної діяльності відбувається опосередковано через їхнє включення у практичну діяльність, вивчення вибіркових дисциплін, проходження навчальної та виробничої практики, організацію i проведення позааудиторної роботи (семінари, конференції, гурткова та науково-дослідницька діяльність, зустрічі 3 керівниками підприємств, організацій тощо).

Професійна діяльність орієнтована, насамперед, на підготовку майбутніх економістів до вирішення завдань професійної діяльності за фахом, однак слабко орієнтована на формування лідерських якостей майбутніх економістів, розвиток їхнього вміння впливати на людей і будувати 3 ними професійні відносини, на становлення індивідуальної системи цінностей і «м'яких умінь», що забезпечують готовність особистості до інноваційних перетворень.

При проходженні навчальної та виробничої практики майбутні економісти ніколи не виступають у ролі суб’єкта управління, суб’єкта прийняття управлінських рішень тощо. Рівень їхньої відповідальності під час проходження практичної підготовки визначається не відповідальністю працівника організації за результати професійної економічної діяльності, а вимогами певного виду (навчальної, виробничої, асистентської тощо) практики.

Відтак, результатом професійної підготовки майбутніх економістів $\epsilon$ готовність до професійної діяльності, а показниками готовності виступають різні компоненти, необхідні для іiі ефективного здійснення. Проведений аналіз дозволив нам визначити готовність майбутніх економістів до професійної 
діяльності як інтегративне особистісне утворення, що $\epsilon$ результатом професійної підготовки у закладах вищої освіти та охоплює здатність провадити ефективну професійну економічну та неперервну самоосвітню діяльність, спрямовану на професійно-особистісний розвиток відповідно до особистих потреб та актуальних професійних вимог до фахівців-економістів. Тому подальший аналіз проблеми дослідження спонукає звернення до такого поняття як «готовність до неперервної самоосвіти».

Суголосно нашим міркуванням, у статті В. Фрицюк схарактеризовано сутнісні характеристики готовності майбутніх фахівців до професійного саморозвитку та іï критеріями визначено «ціннісне усвідомлення професійного саморозвитку; інтегративно-теоретичну та практично-операційну підготовку, сформованість практичних умінь, і навичок щодо професійного саморозвитку; спрямованість на самоаналіз, самооцінку власного професійного саморозвитку» (Фрицюк В.А., 2016, с. 374-384).

У дисертаційній роботі О. Малихін виокремив такі складники потреб у професійній самоосвіті «цілісний емоційно-особистісний апарат, система знань, умінь та навичок самоосвіти; уміння та навички працювати із основними джерелами соціальної інформації та організаційно-управлінські вміння та навички» (Малихін О.В., 2000, с. 7).

У контексті досліджуваної проблеми, нам імпонує дослідження В. Свєтлової, у якому авторка готовність до самоосвіти трактує як властивість особистості, що відрізняється динамічністю та інтегральною єдністю пізнавальної, мотиваційної та практичної готовності до самоосвітньої діяльності на основі прагнення до професійної самореалізації (Светлова В.А., 2013).

У дослідженні С. Юдакова пропонує розглядати готовність до неперервної самоосвіти як цілісний механізм представлений сукупністю двох аспектів: психологічного (особистісна готовність до ефективної неперервної, самостійної та систематичної самоосвіти) та педагогічного (процесуальнодіяльнісні форми прояву відповідних характеристик: мотивів самоосвіти, умінь професійної самоосвіти, здатності до рефлексії) (Юдакова С.В., 2010).

Вказані вище визначення готовності майбутніх економістів до неперервної самоосвіти розширюють наукові погляди на досліджуваний феномен. Однак, на наш погляд, доцільніше розглядати готовність до неперервної самоосвіти як інтегративну особистісну характеристику майбутніх економістів.

У результаті аналізу наукових праць, стандартів вищої освіти 3 економічних спеціальностей, результатів інтерв'ювання роботодавцівстейкхолдерів та викладацького персоналу закладів вищої освіти, власного емпіричного досвіду вважаємо, що готовність майбутніх економістів до професійної діяльності та неперервної самоосвіти має складну структуру, залежну від їхньої здатності до вирішення різних економічних, соціальних, особистісних проблем та явищ професійної діяльності. 
Нами сформовано базовий перелік індикаторів цієї готовності, а саме: здатність приймати цінності сучасного суспільства знань та неперервної освіти впродовж життя; сформована потреба розвивати професійний рівень, лідерські якості, комунікативну культуру, командоутворення, креативність та інші особистісні якості, що забезпечують конкурентоспроможність; здатність критично оцінювати та інтегрувати особистий, вітчизняний та зарубіжний досвід професійної економічної діяльності; сформовані загальні компетентності, наявність навичок і умінь критичного економічного мислення, прогнозування результатів власної професійної діяльності.

До цього дадаємо здатність до відбору та отримання інформації з різних джерел, iї аналізу та інтерпретації в умовах становлення цифрової економіки; усвідомлення та прийняття понять «неперервна самоосвіта», «професійний саморозвиток» та ін.; здатність до наукового аналізу економічної діяльності; сформована культура менеджменту, що передбачає прийняття відповідальності за результати професійної економічної діяльності, прагнення до самовизначення в ситуаціях ціннісного вибору, спрямованість на професійну успішність в умовах жорсткої конкуренції на ринку праці; сформована потреба в саморефлексії, розвиток рефлексійної культури; здатність виробляти індивідуальний стиль економічної поведінки.

Зважаючи на те, що індикатори готовності майбутніх економістів до професійної діяльності та неперервної самоосвіти охоплюють різні ії аспекти умовно ми виокремили такі основні компоненти готовності майбутніх економістів до професійної діяльності та неперервної самоосвіти: мотиваційноціннісний, когнітивний, операційно-діяльнісний та рефлексійно-поведінковий. Схарактеризуємо їх детальніше.

Мотиваційно-ціннісний компонент - ціннісне ставлення до обраної професії, що виявляється у зміні внутрішньої позиції суб'єкта професійної діяльності як базису регуляції спрямованості особистості майбутніми економістами. Ціннісне ставлення до професії формується у процесі усвідомлення і прийняття майбутніми економістами особистісної значущості професійної діяльності та іiі цінностей, що призводить до знаходження особистісних смислів у професійній діяльності та професійній самореалізації.

У дослідженні Е. Новіковою виокремлено такі цінності для становлення професіонала-економіста: відображають особливості діяльності економістів у сучасних умовах і потребують особливої компетентності та відповідальності, оскільки охоплюють питання економічного добробуту суспільства загалом; орієнтують на професійну активність, що передбачає прагнення до неперервного підвищення професійної компетентності (Новікова Е.Ю., 2008).

Вчена додає ще наявність економічного мислення, оволодіння передовими технологіями здійснення діяльності в економічній сфері; орієнтують на розвиток інноваційної культури, що уможливлює здатність вносити до діяльності творчий складник, розробляти, освоювати та використовувати інновації; орієнтують на професійну самореалізацію, що виявляється в креативності здійснюваної професійної діяльності, рефлексії іiі 
результатів, наявності потреби у професійному вдосконаленні (Новікова Е.Ю., 2008).

Особливе місце у мотиваційно-ціннісному компоненті доцільно надати системі мотивів, що забезпечують систематичність, послідовність i продуктивність професійної діяльності та самоосвіти майбутніх економістів. На основі аналізу наукових джерел нами визначено, що цей комплекс мотивів повинен охоплювати: мотивацію досягнення успіху, як прагнення досягти високих результатів у професійній діяльності за рахунок неперервної самоосвіти, що надає самоосвітній діяльності цілеспрямованості та систематичної активності.

До цього переліку залучаємо усвідомлений вибір професії та усвідомлення особистої та професійної значущості професійної діяльності та неперервної самоосвіти, виникнення на цій основі стійкої потреби в ефективній професійній діяльності та самоосвіті як в засобі досягнення особистих i професійних успіхів та самовиховання, що сприяє виробленню цілеспрямованості, внутрішньої організованості, працездатності та інших затребуваних в сучасному соціумі особистісних якостей; пізнавальний інтерес індивідуальна потреба в набутті та оновленні знань, розвитку професійного рівня, лідерських якостей, комунікативної культури, командоутворення, креативності та інших якостей, що забезпечують конкурентоспроможність майбутніх економістів; цілеспрямованість і позитивне ставлення до розширення i поглиблення знань необхідних для продуктивної професійної економічної діяльності.

Когнітивний компонент охоплює обізнаність майбутніх економістів із понятійною системою в галузі основ економічної теорії, менеджменту, маркетингу та соціального підприємництва, управління підприємством тощо; розуміння сутності, вільне оперування економічними поняттями та категоріями («активи», «зобов’язання», «капітал», «рух грошових потоків», «доходи», «витрати», «фінансові результати діяльності організації» тощо); знання змісту різних стратегій поведінки господарюючих суб'єктів на різних ринках i системи соціально-економічних показників діяльності господарюючих суб'єктів; розуміння економічних розділів планів підприємств і організацій різних форм власності та ін.; здатність критично оцінювати та інтегрувати особистий, вітчизняний та зарубіжний досвід професійної економічної діяльності.

Невід’ємним складником когнітивного компоненту, на наш погляд, є розвинене критичне економічне мислення, що уможливлює осмислення майбутніми економістами змісту професійної діяльності, формування цілісних уявлень про роль у ній неперервної самоосвіти. У контексті когнітивного компоненту готовності майбутніх економістів до професійної діяльності та неперервної самоосвіти, на наш погляд, економічне мислення доцільно розглядати як орієнтацію на застосування необхідних когнітивних прийомів вирішення професійних завдань, способів аналізу умов здійснення діяльності та прийняття професійних рішень. 
Отже, можна стверджувати, що професійне мислення майбутніх економістів має характеризуватися економічною спрямованістю і критичністю. Економічна спрямованість і критичність мислення виявляється у розумінні особливостей функціонування державних i ринкових механізмів господарювання, здатності застосовувати набуті економічні знання для прийняття самостійних зважених рішень, високого рівня соціальної відповідальності за результати економічної діяльності.

До складників когнітивного компоненту, на наш погляд, входить: адекватна оцінка майбутніми економістами себе як професіоналів і суб'єктів професійної діяльності та неперервної самоосвіти, об'єктивна оцінка самоефективності; наявність уявлень про сутність і специфіку самоосвіти, іiі ролі в майбутній професійній економічній діяльності.

Наші міркування щодо змістового наповнення когнітивного компоненту базовано на тому, що професійна самореалізація переважно залежить від самооцінки, оскільки ступінь адекватності та стійкості самооцінки впливає на активність майбутніх економістів як суб'єктів професійної та самоосвітньої діяльності. Тому, на наше переконання, принципово важливо, щоб майбутні економісти мали сформовану критичну позицію стосовно власного професійноособистісного потенціалу та можливості його реалізації у процесі професійної діяльності та неперервної самоосвіти.

Операційно-діяльнісний компонент охоплює поєднання репродуктивних, проблемно-творчих, дослідницько-пізнавальних дій у професійній діяльності майбутніх економістів; міждисциплінарність та алгоритмічність професійних умінь та навичок, здатність до переключення 3 однієї діяльності на іншу; здатність до прогнозування економічних явищ і процесів; набуття навичок розроблення рішень з урахуванням фактора невизначеності (етапи, терміни, ресурси), методичних, нормативних документів; здатність оцінювати ефективність професійної економічної діяльності, насамперед, соціальну; вміння розпізнавати ситуації, характерні для професійної економічної діяльності за фахом; вміння реалізовувати різні варіанти дій при вирішенні соціально-економічних проблем.

Окрім викладеного вище, операційно-діяльнісний компонент представлено сукупністю умінь неперервної самоосвіти, під якими ми розуміємо здатність майбутніх економістів до раціонального здійснення самоосвітньої діяльності від визначення цільових установок до отримання конкретних результатів та їхньої оцінки. При цьому під час самоосвітньої діяльності встановлюється взаємозв'язки між іюі цілями, умовами і способами реалізації.

Рефлексійно-поведінковий компонент охоплює здатність до рефлексії та розвинену рефлексійну культуру в професійно-економічній діяльності загалом (навички контролю рівня знань i розвитку вмінь для цілей проектування економічних рішень та прогнозування їх наслідків); здатність до саморегуляції поведінки, що виявляється в неперервному самовдосконаленні та прагненні до 
професійної досконалості, до самореалізації в економічній сфері; самооцінка своєї професійної діяльності, розвинуті вольові якості та емоційна стійкість.

На наш погляд, важливим механізмом регуляції активності майбутніх економістів у професійній діяльності та самоосвіті $\epsilon$ усвідомлена самоефективність як сприйняття здатності до мобілізації особистісних ресурсів для вирішення професійних (теоретичних, практичних) завдань та самоосвіти.

Індивідуальна професійна концепція, на наш погляд, $є$ системою суб'єктивних уявлень про зміст та особливості професійної діяльності майбутніх економістів, тенденції розвитку економічної сфери загалом, сучасних професійних вимог до економістів. Отже, індивідуальна професійна концепція майбутніх економістів, спрямована окреслення не лише персонального бачення майбутньої професії, а й впливає на формування позитивної мотивації щодо професійної діяльності та неперервної самоосвіти, визначення професійно-особистісних пріоритетів та стратегій.

Невід'ємним складником рефлексійно-поведінкового компоненту є емоційно-вольовий, що охоплює здатність до саморегуляції поведінки, розвинені вольові якості та емоційну стійкість. Схарактеризуємо його детальніше. Саморегуляція є визначальним механізмом активності майбутніх економістів як суб' єктів професійної та самоосвітньої діяльності. За допомогою саморегуляції відбувається досягнення стану оптимального режиму активності, що забезпечує раціональність організації професійної та самоосвітньої діяльності: від самомобілізації під час освітнього процесу до вибору конкретних технологій професійної діяльності та неперервної самоосвіти.

Ефективність професійної діяльності та неперервної самоосвіти значно залежить від рівня розвитку вольових якостей майбутніх економістів та їхньої емоційної стійкості, що уможливлює підтримання оптимального рівня професійної та самоосвітньої діяльності під впливом несприятливих, стресогенних, обмежених часових та невизначених факторів.

Висновки. Отже, готовність майбутніх економістів до професійної діяльності передбачає не лише сформованість відповідних професійних якостей, що забезпечують ефективність професійної діяльності, а й, насамперед, доповнюється здатністю до неперервної самоосвіти, яка забезпечує ii результативність. Структура готовності майбутніх економістів до професійної діяльності та неперервної самоосвіти представлена сукупністю мотиваційноціннісного, когнітивного, операційно-діяльнісного та рефлексійноповедінкового компонентів.

Перспективи подальших досліджень вбачаємо у порівняльному аналізі вітчизняного та зарубіжного досвіду формування готовності майбутніх економістів до професійної діяльності.

\section{Jimepamypa}

1. Ссіна О.Г. Критерії оцінки якості підготовки сучасних фахівців. Теорія та методика навчання фундаментальних дисииплін у вищій школі: збірник 
наукових пращъ. Випуск VII. Кривий Ріг : Видавничий відділ НМетАУ, 2012. C. 84-90.

2. Зязюн I. А. Філософія поступу i прогнозу освітньої системи. Педагогічна майстерність: проблеми, пошуки, перспективи: монографія. Київ; Глухів: РВВ ГДПУ, 2005. С.10-18.

3. Максимчук Л.В. Філософсько-методологічний аналіз понятійнокатегоріального апарату професійної підготовки економістів-міжнародників в системі вищої освіти. Вісник Національної академії Державної прикордонної служби України. 2013. Випуск 3. URL: irbis-nbuv.gov.ua/cgibin/irbis.../cgiirbis_64.exe

4. Малихін О.В. Формування у майбутніх учителів потреби в професійній самоосвіті: автореф дис. ... канд. пед. наук: 13.00.04. Харків, 2000. 17 с.

5. Новикова Е.Ю. Ценности и экономическая деятельность. Вестник РЭА им. Г.В. Плеханова. 2008. №4. С.14-21.

6. Остапенко Е.О. Формування готовності майбутніх економістів до професійного саморозвитку: автореф. дис. ... канд. пед. наук: 13.00.04. Київ, 2015. $20 \mathrm{c}$.

7. Светлова В.А. Формирование готовности личности педагога к самообразованию как научная проблема. Современные проблемы науки $и$ образования. 2013.2 № $4 . \quad$ URL: http://www.scienceeducation.ru/ru/article/view?id=9929.

8. Фрицюк В.А. Сутнісні характеристики готовності майбутніх фахівців до професійного саморозвитку. Проблеми інженерно-педагогічної освіти. 2016, № 50-51. С. 374-384.

9. Юдакова С.В. Профессионально-педагогическое самообразование. Владимир, 2010. $131 \mathrm{c.}$

\section{References}

1. Yesina, O.H. (2012). Kryterii otsinky yakosti pidhotovky suchasnykh fakhivtsiv. Teoriia ta metodyka navchannia fundamentalnykh dystsyplin $u$ vyshchii shkoli : zbirnyk naukovykh prats, issue VII, 84-90 (in Ukrainian).

2. Ziaziun, I.A. (2005). Filosofiia postupu i prohnozu osvitnoi systemy. Pedahohichna maisternist: problemy, poshuky, perspektyvy: monohrafiia. Kyiv; Hlukhiv: RVV HDPU (in Ukrainian).

3. Maksymchuk, L.V. (2013). Filosofsko-metodolohichnyi analiz poniatiino-katehorialnoho aparatu profesiinoi pidhotovky ekonomistivmizhnarodnykiv $\mathrm{v}$ systemi vyshchoi osvity. Visnyk Natsionalnoi akademii Derzhavnoi prykordonnoi sluzhby Ukrainy, issue 3. URL: irbis-nbuv.gov.ua/cgibin/irbis.../cgiirbis_64.exe (in Ukrainian).

4. Malykhin, O.V. (2000). Formuvannia u maibutnikh uchyteliv potreby v profesiinii samoosviti. Extended abstract of candidate's thesis. Kharkiv [in Ukrainian].

5. Novikova, E.Ju. (2008). Cennosti i jekonomicheskaja dejatel'nost'. Vestnik RJeA im. G.V. Plehanova. 2008. №4. 14-21. (in Russian). 
6. Ostapenko, E.O. (2015). Formuvannia hotovnosti maibutnikh ekonomistiv do profesiinoho samorozvytku Extended abstract of candidate's thesis. Kiyv (in Ukrainian).

7. .Svetlova, V.A. (2013). Formirovanie gotovnosti lichnosti pedagoga k samoobrazovaniju kak nauchnaja problema. Sovremennye problemy nauki $i$ obrazovanija. № 4. URL: http://www.scienceeducation.ru/ru/article/view?id=9929. (in Russian).

8. Fricjuk, V.A. (2016). Sutnisni harakteristiki gotovnosti majbutnih fahivciv do profesijnogo samorozvitku. Problemi inzhenerno-pedagogichnoï osviti, № 50-51, 374-384. (in Ukrainian).

9. Judakova, S.V. (2010). Professional'no-pedagogicheskoe samoobrazovanie. Vladimir (in Russian). 